\title{
Evaluation of water use structure and regulation to balance supply and demand in the Nansi Lake basin, China
}

\author{
Lingling Zhang ${ }^{1} \cdot$ Zongzhi Wang $^{2}$ (i) $\cdot$ Yanqing Lian $^{3} \cdot$ Xiao Zhang $^{4}$
}

Received: 1 June 2015/Accepted: 21 September 2015/Published online: 1 October 2015

(C) Springer International Publishing 2015

\begin{abstract}
In an established water supply system, the increasing demand for water resources caused by economic growth becomes a key issue for water resource management in China. From the water demand management perspective, this paper analyzed the mechanism of internal feedbacks among water resources, population, and economic mutual effects and established a system dynamics model to simulate the evolution and regulation of water use structure under the business-as-usual, and the high, middle, and low economic growth strategies in the Nansi Lake basin. This study showed although the regulation strategy of the middle scheme production structure can improve water use structure without impeding economy growth, the supply of water cannot meet the demand in the basin. However, a comprehensive regulation strategy can address this water shortage. By optimizing the water use structure, this comprehensive regulation strategy can lower quota of water uses and improve the efficiency of agricultural irrigation and production thus to balance water supply and demand in the basin.
\end{abstract}

Zongzhi Wang

wangzz77@163.com

1 School of Public Administration, Hohai University, Nanjing, China

2 Key Laboratory of Hydrology Water Resources and Hydraulic Engineering, Nanjing Hydraulic Research Institute State, Nanjing, China

3 Illinois State Water Survey, Prairie Research Institute, University of Illinois at Urbana-Champaign, Champaign, USA

4 Pacific Northwest National Laboratory, Richland, USA
Keywords Total water amount control - Water use structure regulation - System dynamics - Dynamic simulation · Nansi Lake basin

\section{Introduction}

Since the end of the twentieth century, problems caused by water shortage and the deterioration of water environment have seriously restricted the sustainable economic and societal development in China (Sustainable Development Strategy Research Group of Chinese Academy 2007). These water-related problems were due to the long-term cumulative effects from sewage discharge and improper waste disposal. Discharges from sewage and domestic and industrial wastes have exceeded the carrying capacity that the water environment can bear as a result of population increase and extensive economic growth in recent years in China (Hu et al. 2010). In 2011, the Chinese government released the No. 1 Central Document named "CPC Central Committee and the State Council on accelerating the development of water conservancy reform decision". The nineteenth item of the document is to control the total water use and pay close attention to water allocations for major rivers, to the development of the index system for total water use control, and to the development and utilization of water resources (CPC Central Committee, State Council 2011).

Water resources are essential for the national economy and indispensable for life and production (Kang et al. 2009). Changes in the distribution of water and allowable water resources will have direct impacts to some economic sectors, and consequently impacts on these sectors will affect other economic sectors. This chain reaction will require adjustment of water distribution over a large region. 
Therefore, it is imperative and also challenging for scientists in China to develop research approaches or techniques for adaptive management of water resources on basin scale thus to adjust the water use structure to improve the water use efficiency, and to make the economic social development of the river basin adaptive to the restriction of water resources.

The input-output analysis model and its extension have been used for studies on regulations of industrial structure with water resources as constraints (Liao 2009; Shen 2006; Fang 2010; Comez 2004; Jennifer 2005). This method, unfortunately was not able to take changes in water resource supply into consideration. A computable general equilibrium model (CGE) is the extension of the input-output analysis model (Zhao et al. 2008; Wang 2004). This model is able to consider the change of water resource supply to production sectors, the change of demand from consumers, and the supply-demand relation. It has been evolved into a relatively standardized model for water resource system analysis. Unfortunately, its application is limited by the difficulty of being able to accurately describe the complex system needs of basin water use.

System dynamics (SD) (Forrester 1971; Wang 1995) is one kind of quantitative method based on feedback control theory, which uses the digital computer simulation technology to study the complex social economic system. This quantitative method is suitable for a combination of qualitative and quantitative analysis of a social economic system. It can also be used as an actual system "laboratory" for medium- and long-term analysis and prediction. In water resource management, the SD method has been broadly used for urban water systems (Zarghami et al. 2012; Qi et al. 2011), water ecological carrying capacity (Zhang et al. 2014; Wang et al. 2014), integrated system dynamics modeling (Sušnik et al. 2012; Qin et al. 2011; Hassanzadeh et al. 2014), water resource planning (Zhang et al. 2008), system dynamics with stakeholders (Winz et al. 2009; Stave 2003), changing climatic conditions (Dawadi et al. 2012; 2013), global water resource modeling (Davies et al. 2011; Kojiri 2008), as well as sustainable development (Rehan 2013). However, there are few studies on the application of this SD method for simulating the evolution and regulation of water use for socio-economic development on a basin scale under the constraints of total water use and strictest water management system in China. In this study, a complex water use for socio-economy system was developed for the Nansi Lake basin and has been used to explore the evolution of water use structure, to diagnose existing problems in water use structure, and to provide regulation strategies in the Nansi Lake basin. The dynamic simulation of the evolution and regulation in the Nansi Lake basin water use structure involves four objectives: (1) defining water use structures; (2) determining the quantity of total water supply under total quantity control constraints; (3) designing and simulating regulation strategies of water use structure; (4) selecting regulation schemes of water use structure.

\section{Study area and data sources}

The Nansi Lake is located in Shandong Province of China (Fig. 1). It is the largest freshwater lake in northern China with a surface area of about $1266 \mathrm{~km}^{2}$, divided into two parts by the dam named Erjiba. This lake is fed by fiftythree rivers, among them there are nine rivers with a drainage area of more than $1000 \mathrm{~km}^{2}$, from Shandong, Jiangsu, Henan, and Anhui provinces. This lake is expected to play an important role for east route of the South-to-North Water Transfer Project. The Nansi Lake basin has a drainage area of $31,700 \mathrm{~km}^{2}$. Total population in the basin had reached $20,534,000$ in 2010. The nonagricultural population is $6,303,000$ people, and the agricultural population is $14,231,000$ accounting for $69.3 \%$ of the total population. The population mostly concentrates around the lake and the canal, and a small portion lives around the east lake and near the south bank of the Yellow River. The per capita water resource is less than $300 \mathrm{~m}^{3}$, which places it in a serious water resource shortage area. The average GDP within the basin was about 140.43 billion yuan in 2000 and increased to 462.84 billion yuan in 2010 .

Water use in the basin can be classified into five major sectors: (1) the primary water use, (2) the secondary water use, (3) the tertiary water use, (4) domestic water use, and (5) environmental water use. The primary, secondary and tertiary water use is usually called production water use. The primary water use was mainly for irrigation of croplands, accounts for the largest proportion. The tertiary and environmental water use sectors use less water than the first three sectors but are in the stage of steady growth. Figure 2 shows the change of industrial structure in the Nansi Lake basin from 2000 to 2010. It can be seen that the primary sector added value proportion declines, with an annual reduction of $1.5 \%$; the secondary and tertiary sector added value proportions are gradually on the rise.

Data used in this study were obtained from several sources. Industrial structure data was from the "Shandong Statistical Yearbook" (2000-2010) and "Statistical Yearbook of Jining City" (2000-2010); Water use structure data were from the "Shandong Province Water Resources Bulletin" (2010); "Jining City Water Resources Bulletin" (2010) and "Heze City Water Resources Bulletin” (2010) (Fig. 3). 


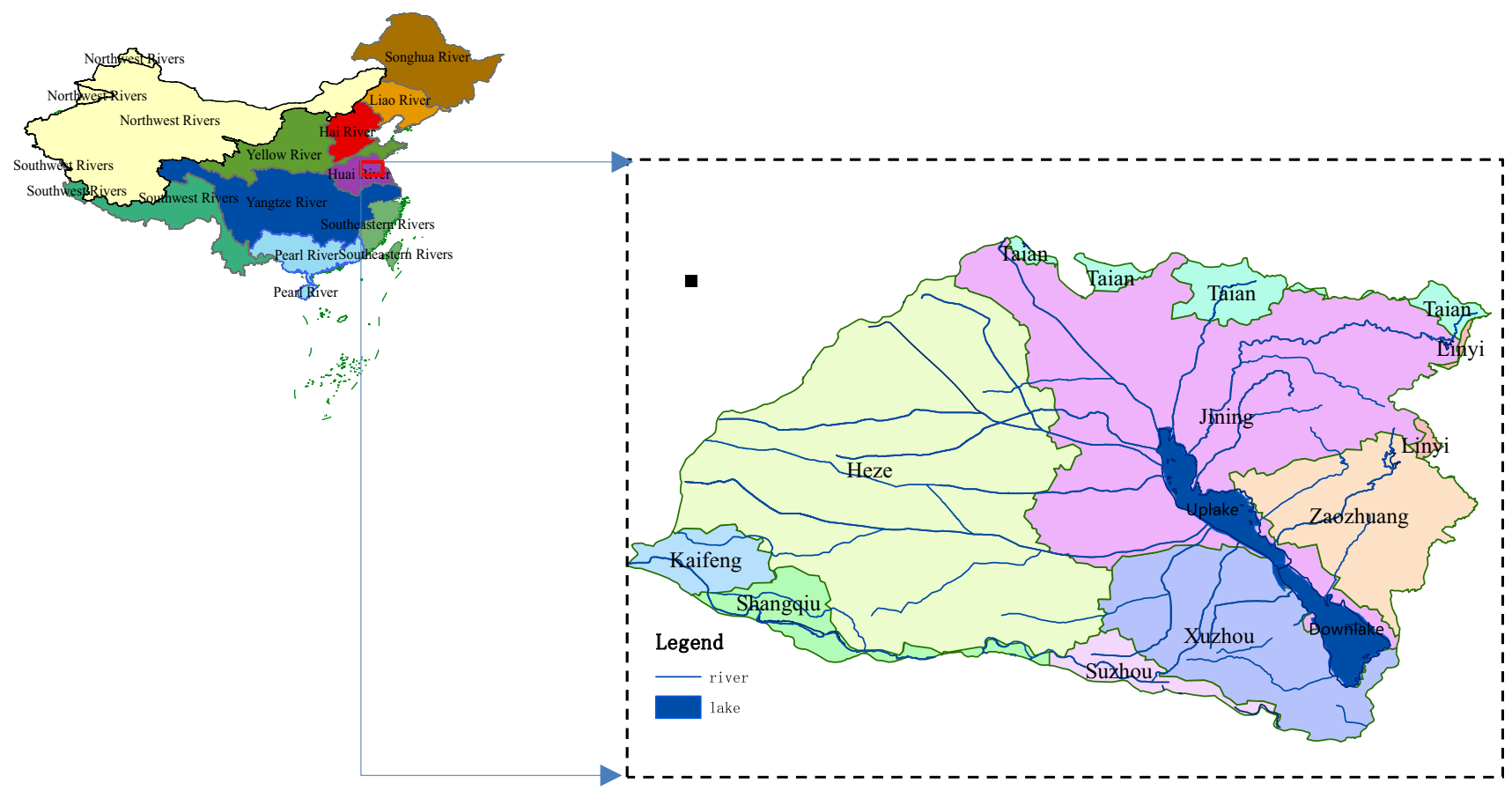

Fig. 1 Nansi Lake basin location map

Fig. 2 2000-2010 Industrial structure of the basin

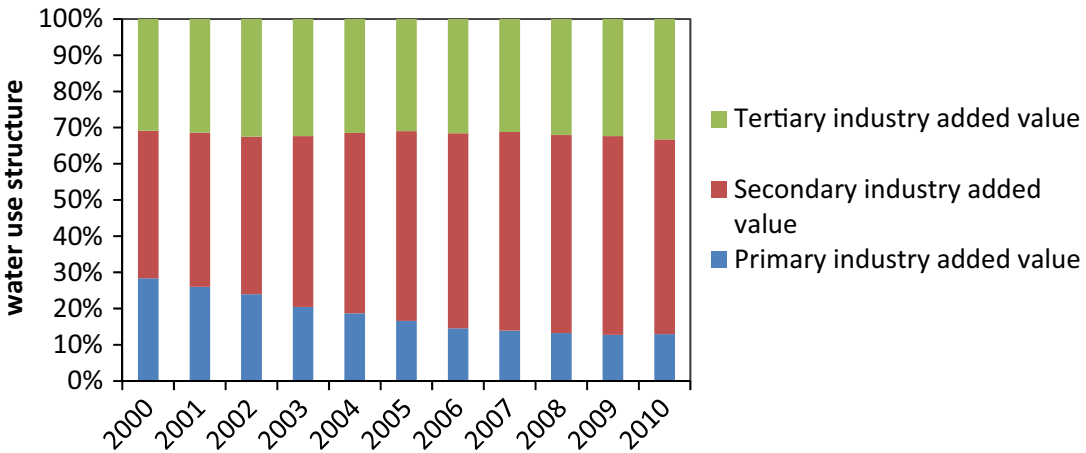

The modeling process of a system dynamics model is to simulate and reproduce the main causation of various elements in the system; the causal graph is the direct embodiment of causality. There are multiple positive and negative feedbacks between an economic system and a water resource system. The main causal feedbacks are shown in Fig. 4.

In the model, water use structure is mainly affected by population, available water resources, GDP, and some other factors such as water price and water policy. As shown in Fig. 4, to increase environmental water would improve the quality of ecological environment, which will then lead to a more conventional water resource supply and to have a positive feedback to the sustainable development of water resources (R1). To increase industrial water would produce sewage discharge, and the increase in treated sewage water would increase the supply of available water
To describe the evolution process and the characteristics of water use structure, 2007 was selected as the base year. The simulation interval was 1 year. 


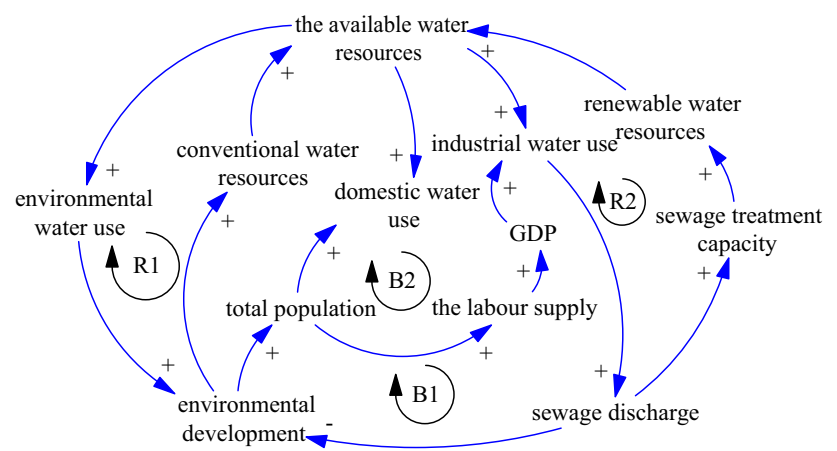

Fig. 4 Main cause and effect relation between economy and water resource systems

resources. So there is a positive feedback for available water supply (R2). On the other hand, an increase in sewage discharge would cause environmental deterioration, and reduction of population and labor force would reduce the GDP and subsequently would create a negative feedback loop (B1). An increase in the sewage discharge would require to use more conventional water resources for environmental development and thus to have a negative feedback in loop B2.

Water use structure changes under different economic development strategies and the corresponding relation between water use structure and industrial structure would be simulated. System dynamic stock-flow diagram is shown in Fig. 5, and abbreviation description in this diagram is shown in Table 3 in "Appendix".

Listed in Table 1 are the main parameters for water use structure simulation model of Nansi Lake basin.

The model was calibrated using the historical testing spectrum from 2006 to 2010 . The stocks of total population, basin GDP, farmland irrigation water of the Nansi Lake basin were compared using their simulation values with the actual values. The maximum error between the stock simulated values to the actual value from calibration was $-4.58 \%$, indicating a good match with historical data. Yet it is not the only basis for the validity of the model, because the operation and output of an error model can possibly also have a good match with the historical data. A reasonable standard model depends on the causal model construction. The feedback structure was reasonable, the feature of water resource system in the Nansi Lake basin was expressed, and the calibration of the SD model met the accurate requirements. So the model can be used for simulating and predicting the dynamic process of future water use structures in the Nansi Lake basin under different scenarios.

\section{Scenarios analysis}

\section{Sensitivity analysis of model parameters}

The basic idea of the regulation strategy design of a water use structure is as follows: calculating model outputs by changing one variable while keeping other parameters unchanged. So the variable selection is very important because they are the basis for regulation strategy design. The selected variables should not only reflect the water resource supply and demand in the Nansi Lake basin but also consider the comprehensive social, economic and environmental effects. First of all, by analyzing sensitivity, it was found out that the main determinants of water use structure regulation. Secondly, the low, middle, and high economic development strategies were designed and simulated according to the economy and water resource development planning in Shandong province and the Nansi Lake basin. Based on the results for the low, middle and
Fig. 5 SD stock-flow diagram of water use structure simulation of Nansi Lake basin

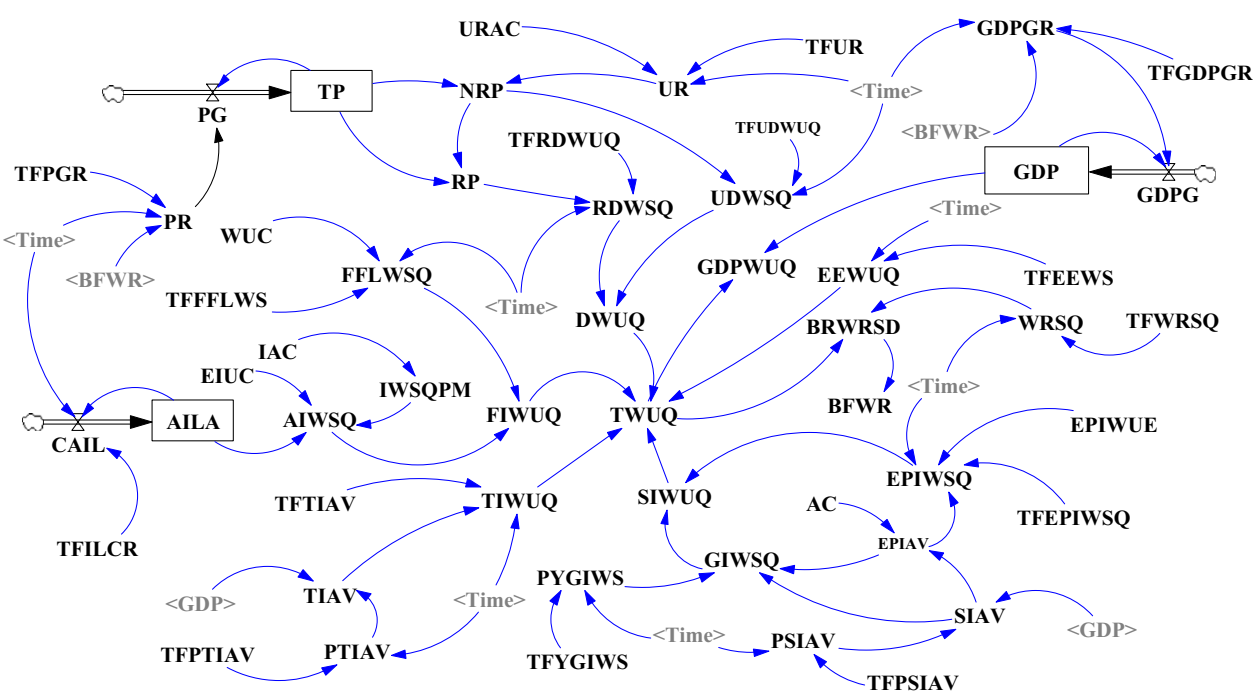


Table 1 SD parameters of water use structure simulation of Nansi Lake basin

\begin{tabular}{lll}
\hline Main parameters & Base year (2007) & 2015 \\
\hline Urbanization rate $(\%)$ & 29.65 & 2025 \\
Population growth rate (\%) & 7.93 & 40 \\
GDP annual growth rate (\%) & 14.18 & 8.00 \\
Agricultural irrigation water quota $\left(\mathrm{m}^{3} / \mathrm{mu}\right)$ & 280 & 8.16 \\
Water use of general industrial per $10^{4}$ yuan added value $\left(\mathrm{m}^{3} / 10^{4}\right.$ yuan) & 17.28 & 250 \\
Water use that power industrial per $10^{4}$ yuan added value $\left(\mathrm{m}^{3} / 10^{4}\right.$ yuan) & 145.1 & 12 \\
Water use that third industrial per $10^{4}$ yuan added value $\left(\mathrm{m}^{3} / 10^{4}\right.$ yuan) & 6.6 & 95 \\
Environmental water use $\left(10^{8} \mathrm{~m} 3\right)$ & 0.238 & 9.8 \\
Utilization coefficient of irrigation water & 0.53 & 1.00 \\
Rural residents water consumption quota (L/d) & 50 & 0.62 \\
Urban residents water use quota (L/d) & 86 & 1.44 \\
\hline
\end{tabular}

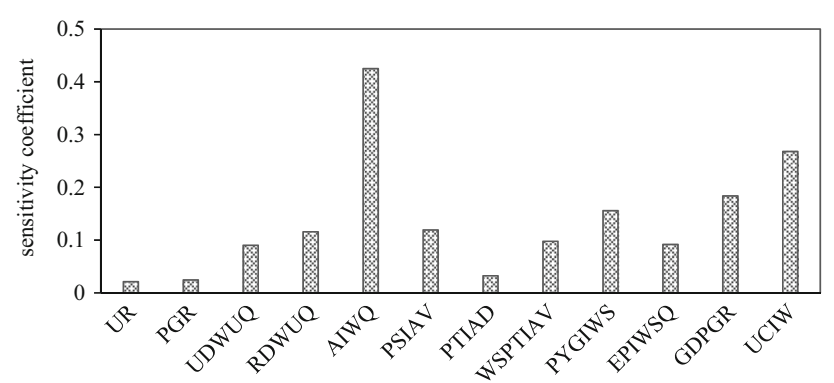

Fig. 6 Sensitivity analysis of total water use of Nansi Lake basin

high scenarios, the middle scheme was selected for further simulation. Thirdly, the industrial structure regulation strategy and the comprehensive regulation strategy of water use structure were designed to simulate the total water demand, and water use structure changes under different schemes.

To determine the regulatory variables of water use structure, sensitivity analysis for the model main variables had to be done. Water demand sensitivity analysis is mainly to analyze the significance of an effect, and then identifies the key factors that affect the total water demand of basin. The calculation formula is as follows:

$S_{q}=\left|\frac{\Delta q(t)}{q(t)} \cdot \frac{x(t)}{\Delta x(t)}\right|$,

where $q(t)$ is the value of total water demand $q$ at the time of $t, x(t)$ is the value of variable $x$ at the time $t, t$ is time. $\Delta q(t)$ and $\Delta x(t)$, respectively, represent the incremental value of total water demand $q$ and variable $x$ at the time of t. $S_{q}$ is the sensitivity that total water demand $q(t)$ to variable $x(t)$.

This paper mainly analyzes the sensitivity of twelve parameters that influence the total water demand and water demand quantity. Sensitivity analyses of these 12 parameters for the Nansi Lake basin using data from 2007 to 2025 are shown in Fig. 6. According to the formula (1), sensitivities of 12 parameters were computed for every year in simulation period for the sensitivity mean values.

Figure 6 shows the average sensitivities for agricultural irrigation water quota (AIWQ), the utilization coefficient of irrigation water (UCIW), GDP growth rate (GDPGR), per $10^{4}$ yuan general industrial added value water use (PYGIWS), the proportion of the secondary industrial added value (PSIAV), and rural domestic water use quota (RDWUQ) were greater than $10 \%$. The sensitivity for the agricultural irrigation water quota (AIWQ) was as high as $42.5 \%$, indicating that the most important factor affecting the total water demand is the amount of water used for irrigation. Sensitivities for urban domestic water use quota (UDWUQ), water use for the tertiary industrial per $10^{4}$ yuan added value (WSPTIAV), and electric power industrial water use quota (EPIWSQ) were between 5 and $10 \%$. Sensitivities for urbanization rate (UR), population growth rate (PGR), the proportion of the tertiary industrial added value (PTIAD) were lower than $5 \%$.

\section{Water use quantity simulation}

The supply and demand simulation of water resources is shown in Fig. 6 in business-as-usual scenario. The total water demand would increase with an average annual growth of 88.39 million $\mathrm{m}^{3}$ and $1.4 \%$ from 2011 to 2025 . Total water demand would reach 7.191 billion $\mathrm{m}^{3}$ by 2025 . The average annual growth of available water resource supply is 37.07 million $\mathrm{m}^{3}$, with an average annual growth rate of less than $1 \%$. So the contradiction between demand and supply of water resources will result in a serious water shortage. The water shortage in 2011 was 0.572 billion $\mathrm{m}^{3}$, and was about $9.45 \%$. By 2025, the total water shortage would be 1.073 billion $\mathrm{m}^{3}$, and would be by $14.93 \%$. Water shortage will directly affect the healthy development of the basin social economy. From 2011 to 2025, water consumption per $10^{4}$ yuan GDP in the Nansi Lake basin 


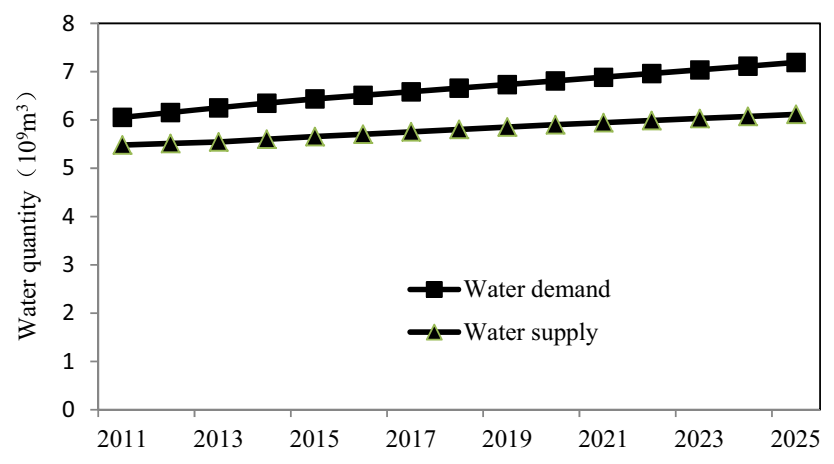

Fig. 7 Supply and demand of water resources of Nansi Lake basin in 2011-2025

would decrease from 116.02 to $50.07 \mathrm{~m}^{3}$ or by $58 \%$. Over the same period, the water consumption per capita would increase from 292.63 to $312.60 \mathrm{~m}^{3}$, but would be still lower than the national average.

Figure 7 shows that the water demand is higher than the water supply. The average shortage of water resources reaches 0.823 billion $\mathrm{m}^{3}$ and the gap between supply and demand would get larger year by year, which would affect the sustainable development of society, economy and ecological environment of the Nansi Lake basin.

\section{Simulation of water use structure}

As shown in Fig. 7, the total water use in the Nansi Lake basin was 6.045 billion $\mathrm{m}^{3}$ in 2011, among which the residential water use, industrial water use, and environmental water use were $0.516,5.466$, and 0.072 billion $\mathrm{m}^{3}$, or $8.5,90.4$, and $1.1 \%$ of the total water consumption, respectively. The primary, secondary, tertiary industrial water uses were $4.87,0.509$, and 0.086 billion $\mathrm{m}^{3}$, or 89.2 , 9.3 , and $1.5 \%$ of total industrial water use, respectively.

Figure 8 also shows that the water use for the primary sector would decrease from $80.4 \%$ in 2011 to $72.7 \%$ in 2025. Although the amount of water use for the primary industry would increase slightly, its percentage in the total water consumption would decrease. The secondary industrial water use would increase from $8.4 \%$ in 2011 to $12.8 \%$ in 2025 . The tertiary industrial water use would increase from $1.4 \%$ in 2011 to $2.5 \%$ in 2025 . The increase of residential water use would be from $8.5 \%$ in 2011 to $10 \%$ in 2025. Ecological and environmental water use is the smallest portion and would increase from $1.2 \%$ in 2011 to $2 \%$ in 2025.

From the water use structure of the basin, industry water use occupies about $88 \%$ of total water use in the Nansi Lake basin, with the primary, the secondary and the tertiary water use sectors accounting for 75,10 , and $3 \%$, respectively. Yet the industrial value structure is 0.13:0.54:0.3. The industrial added value structure and the water use structure are difficult to match each other because the shortage of water limits economic development. At the same time, low water utilization rate leads to a waste of water. The mismatch of industrial structure and water use structure has seriously affected the sustainable use of water resources and a healthy economic development.

\section{Results and discussion}

\section{Low, middle and high growth patterns}

The predicted water demands for three economic development schemes, i.e., high, middle, and low, are shown in Fig. 9a. Figure $8 \mathrm{~b}$ are ratios between water supply and demand for the three schemes. The middle scheme refers to the average GDP growth in the Nansi Lake basin for the past 10 years combined with the predicted average GDP growth for 2010-2030. The high and low schemes represent GDP growths that are $10 \%$ higher and lower than the middle scheme.

As seen in Fig. 9a, b, total water demand under high, middle, and low economic growth scenarios would be 7.217 billion $\mathrm{m}^{3}, 7.128$ billion $\mathrm{m}^{3}$, and 7.045 billion $\mathrm{m}^{3}$, respectively, by 2025 . The variation of growth rate for total
Fig. 8 Water use structure of Nansi Lake basin in 2011-2025
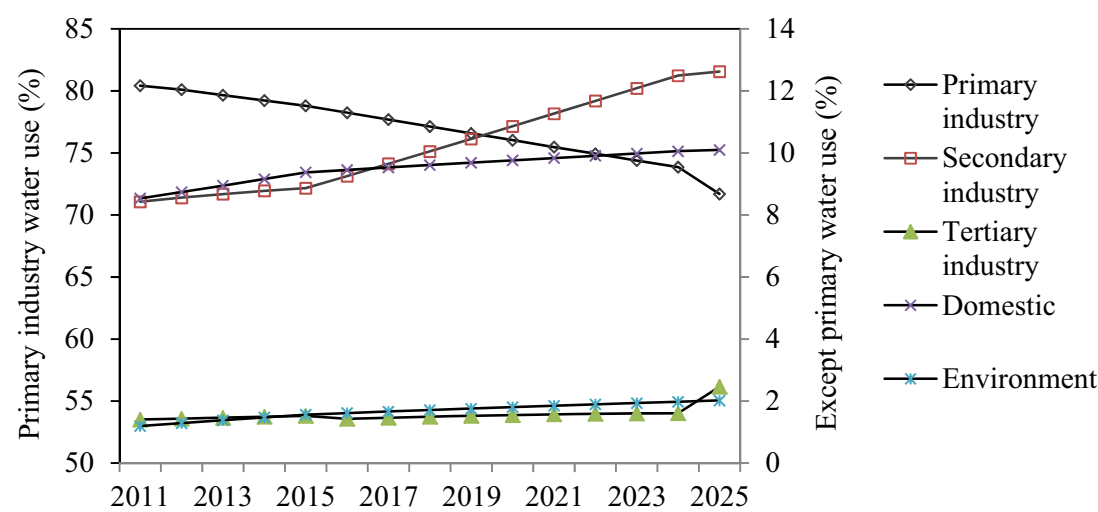

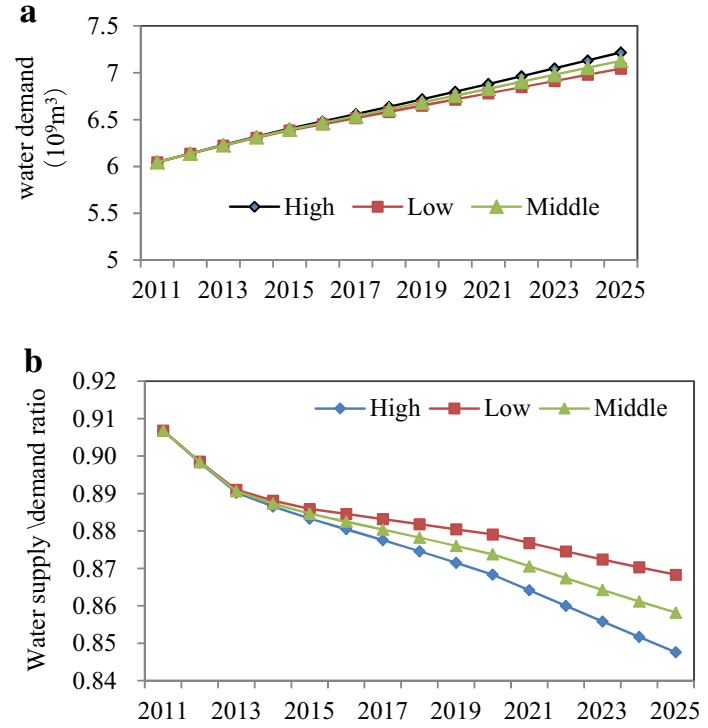

Fig. 9 a Total water demand. b Ratio of supply to demand of water under different economic schemes

Table 2 Water use structure of the basin in typical year under different economic schemes

\begin{tabular}{lrrrr}
\hline Water use structure & Year & High $(\%)$ & Middle $(\%)$ & Low $(\%)$ \\
\hline The primary sector & 2015 & 78.69 & 78.80 & 78.92 \\
& 2020 & 75.55 & 76.02 & 76.49 \\
& 2025 & 72.44 & 73.34 & 74.20 \\
The secondary sector & 2015 & 8.98 & 8.88 & 8.74 \\
& 2020 & 11.34 & 10.93 & 10.33 \\
The tertiary sector & 2025 & 13.84 & 13.05 & 11.86 \\
& 2015 & 1.41 & 1.40 & 1.37 \\
Domestic & 2020 & 1.62 & 1.56 & 1.48 \\
& 2025 & 1.73 & 1.63 & 1.48 \\
& 2015 & 9.36 & 9.37 & 9.39 \\
Environment & 2020 & 9.70 & 9.76 & 9.82 \\
& 2025 & 10.01 & 10.13 & 10.25 \\
& 2015 & 1.56 & 1.56 & 1.57 \\
& 2020 & 1.79 & 1.81 & 1.82 \\
& 2025 & 2.00 & 2.02 & 2.04 \\
\hline
\end{tabular}

water demand is less than economic growth. Ratios between water supply and demand would be $84.76,85.82$, and $86.83 \%$, respectively, in 2025 . The increase of total water demand for economic expansion and the lower balance ratio of water demand and supply make economic development difficult to sustain.

Water use structures for the high, middle, and low scenarios in 2015, 2020, and 2025 are shown in Table 2. A comparison of water use structures for high, middle and low economic schemes shows that water uses for the secondary and tertiary sectors are highest in the high scheme and lowest in the low scheme. The primary sector, domestic, and ecological and environmental water uses are lowest in the high scheme, and highest in the low scheme, which implies economic growth would be constrained by high water demand from high economic growth rate. Although low economic development can alleviate water shortage to certain extent, relatively lower GDP would bring adverse effects on the household lives, for example, reductions in the capital and technological investment for water supply infrastructures.

\section{Production structure regulation pattern}

It is difficult to eliminate the imbalance of water supply and demand in the Nansi Lake basin. This section will discuss the development of an optimal water use structure that integrates social economic development and water resource constraints.

The primary, secondary, and tertiary sector added value accounted for $12.9,53.8$, and $33.3 \%$ of the total GDP in the Nansi Lake basin in 2010, respectively. The water use for primary, secondary, and tertiary sectors were 80.7, 8.6, and $1.3 \%$ of the total industrial water use, respectively. These data showed a mismatch between production structure and water use structure. The primary sector added value was the lowest, yet its water use was the largest. The structures of the secondary sector and the tertiary sector are moderately adjusted, and the economy proportion of the tertiary sector is increased. So the economic added value ratios of above three sectors are 8.1:52.3:39.6 in 2015, and 6.1:48.9:45.0 in 2025.

Change trends of water use structure from 2011 to 2025 in the Nansi Lake basin under industrial structure regulation strategy are shown in Fig. 10. The total water demand would be reduced from 7.128 billion $\mathrm{m}^{3}$ in 2011 to 6.896 billion $\mathrm{m}^{3}$ in 2025 , with an annual reduction of 0.188 billion $\mathrm{m}^{3}$. The water savings due to the structure adjustment were $2.4 \%$ in 2011 and would be $3.3 \%$ in 2025 .

The primary, secondary, and domestic water uses are expected to be reduced by $0.27,0.93$, and $0.24 \%$, respectively, when adopting an adjusted water use structure. On the other hand, the tertiary sector and the environmental water use would be increased by 1.62 and $0.07 \%$, respectively, in 2025. Although this adjusted water use structure is more reasonable, the contradiction between water supply and demand is still obvious, and the water shortage problem still exists.

\section{Comprehensive regulatory strategy}

To meet the demand of water, a comprehensive regulatory strategy was developed by taking into account the agricultural irrigation water use, utilization coefficient of 
Fig. 10 Total water demand quantity comparison
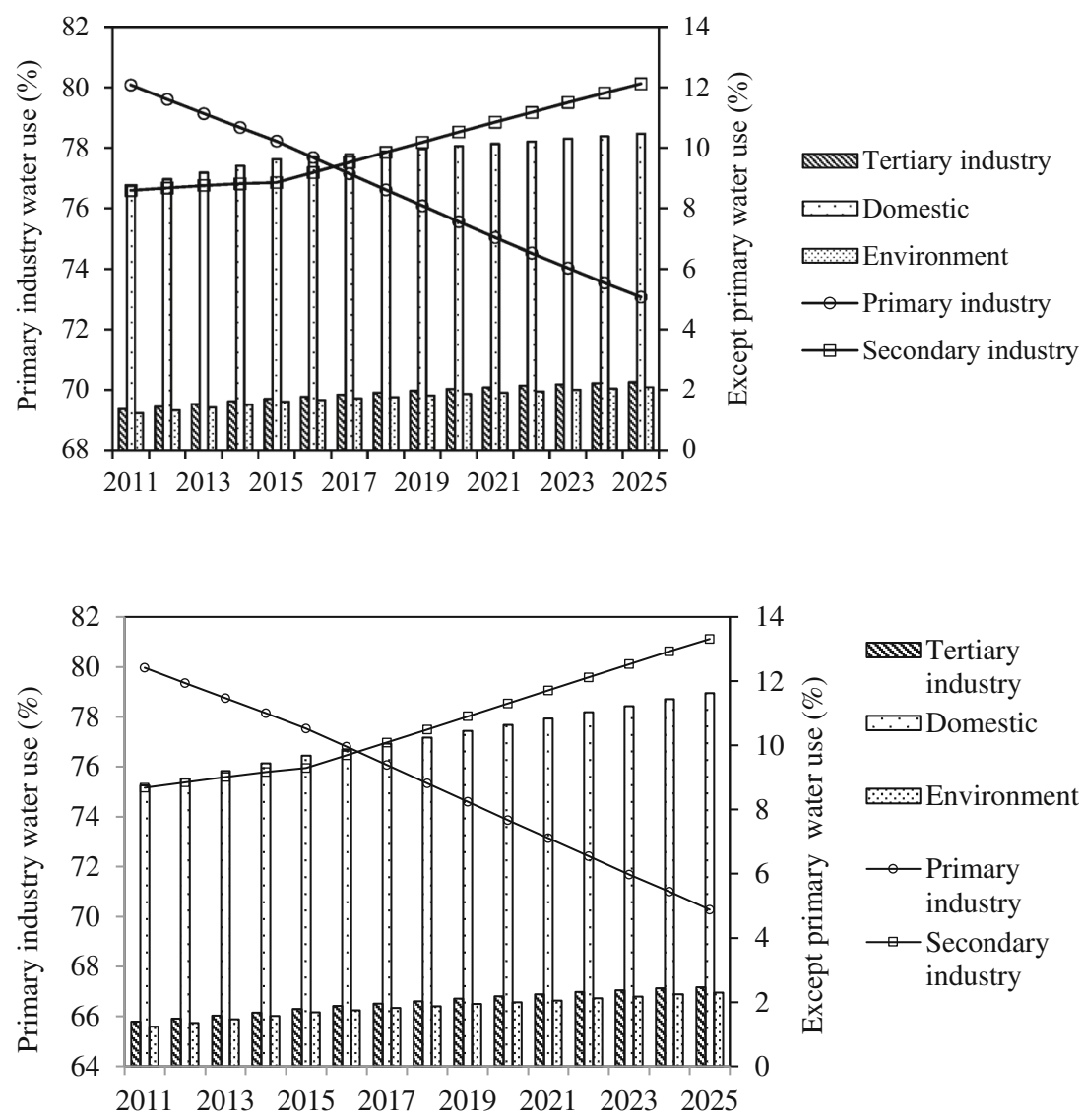

Fig. 11 Water use structure of Nansi Lake basin in comprehensive regulation irrigation water, the tertiary industrial water consumption of per $10^{4}$ yuan, the urban residents water quota, the rural residents water quota, and the general industrial water use per $10^{4}$ yuan as the regulatory variables. Figure 11 shows the water use structure for the comprehensive regulation.

The total water demand for the comprehensive regulatory scheme, in the Nansi Lake basin, would be 6.278 billion $\mathrm{m}^{3}$ by 2025 , and the water supply to demand ratio is 0.97 , which indicates that water supply can almost meet the water demand. The primary, secondary, and tertiary sector industrial water use would be $70.3,13.3$, and $2.5 \%$, respectively, which conforms to the development trend of social economy in the basin and could balance water use structure and industrial structure.

\section{Conclusions}

The speed of economic development in the basin has an effect on water use structure. When the economic growth rate increases, water uses for the secondary and tertiary water use sectors would increase. This study showed that the economic growth would be about $10 \%$ and increase of the secondary and the tertiary industrial water uses would be about 6 and $6.1 \%$, respectively. At the same time, the agriculture, domestic, and environmental water uses would decrease by $1.2,1.1$, and $0.9 \%$, respectively. This study also showed that a slower economic growth would increase the agricultural, domestic, and environmental water uses and reduce water uses in the secondary and tertiary sectors. The effect of economic growth on water use structure is due to the increase in demand for water uses in the secondary and tertiary sectors.

Effects on the basin wide water use structure vary with regulations for the production water use structure. Results from this study indicate promoting the tertiary sector water use and limiting power industrial growth would be a healthy water use structure, in which the primary and secondary sector water use ratio would decrease, the domestic and environmental water use ratio remains constant, and the tertiary sector water use would increase greatly. This production structure regulation can improve water use structure without impeding the economy growth, but the water resource supply still cannot meet the demand in the basin.

This water shortage issue can be addressed by a comprehensive regulation strategy. Based on the low, middle and high economic growth strategies and the production structure regulation strategy, the comprehensive regulation strategy would further lower the water quota and improve 
the efficiency of agricultural irrigation and production thus to balance water supply and demand. The comprehensive strategy can not only optimize water use structure in the basin, but also ease shortage of water supply.

Acknowledgements Support for this research was provided by a grant from the National Natural Science Foundation of China (No. 51109055, 51279223, 51479119), the National Soft Science Research Program (2014GXS4B047), the Public-services Foundation of Ministry Water Resources of China (No. 201301003, 201201022), and the Social Science Foundation from the Jiangsu Province (No. 11GLA001)

\section{Appendix}

See Appendix Table 3.

Table 3 Abbreviations for variables and parameters in the Nansi Lake basin SD model

\begin{tabular}{|c|c|c|}
\hline Abbreviations & Description & Unit \\
\hline TWUQ & The total water use quantity & $10^{8} \mathrm{~m}^{3}$ \\
\hline FIWUQ & The primary sector water use quantity & $10^{8} \mathrm{~m}^{3}$ \\
\hline SIWUQ & $\begin{array}{l}\text { The secondary industrial water use } \\
\text { quantity }\end{array}$ & $10^{8} \mathrm{~m}^{3}$ \\
\hline TIWUQ & $\begin{array}{l}\text { The tertiary industrial water use } \\
\text { quantity }\end{array}$ & $10^{8} \mathrm{~m}^{3}$ \\
\hline DWUQ & Domestic water use quantity & $10^{8} \mathrm{~m}^{3}$ \\
\hline EEWUQ & $\begin{array}{l}\text { Ecological and environmental water use } \\
\text { quantity }\end{array}$ & $10^{8} \mathrm{~m}^{3}$ \\
\hline AIWSQ & $\begin{array}{l}\text { Agricultural irrigation water use } \\
\text { quantity }\end{array}$ & $10^{8} \mathrm{~m}^{3}$ \\
\hline IWSQPM & Irrigation water use quantity of per mu & $\mathrm{m}^{3} / \mathrm{mu}$ \\
\hline AILA & Agricultural irrigation land area & $\mathrm{mu}$ \\
\hline UCIW & $\begin{array}{l}\text { Utilization coefficient of irrigation } \\
\text { water }\end{array}$ & \\
\hline IAC & Irrigation adjustment coefficient & \\
\hline CAIL & The change area of irrigation land & $\mathrm{Mu}$ \\
\hline TFILCR & $\begin{array}{l}\text { The table function of irrigation land } \\
\text { change rate }\end{array}$ & $\%$ \\
\hline FFLWSQ & $\begin{array}{l}\text { Forestry, fishing, livestock water use } \\
\text { quantity }\end{array}$ & $10^{8} \mathrm{~m}^{3}$ \\
\hline WUC & Water utilization coefficient & \\
\hline TFFFLWS & $\begin{array}{l}\text { The table function of forestry, et al. } \\
\text { water use }\end{array}$ & $10^{8} \mathrm{~m}^{3}$ \\
\hline SIAV & The secondary industrial added value & $10^{8}$ yuan \\
\hline PSIAV & The proportion of SIAV & $\%$ \\
\hline TF PSIAV & The table function of PSIAV & $\%$ \\
\hline GIWSQ & General industrial water use quantity & $10^{8} \mathrm{~m}^{3}$ \\
\hline PYGIWS & $\begin{array}{l}\text { Per } 10^{4} \text { yuan general industrial added } \\
\text { value water use }\end{array}$ & $\begin{array}{c}\mathrm{m}^{3} / 10^{4} \\
\text { yuan }\end{array}$ \\
\hline TFYGIWS & The table function of PYGIWS & $\begin{array}{c}\mathrm{m}^{3} / 10^{4} \\
\text { yuan }\end{array}$ \\
\hline
\end{tabular}

Table 3 continued

\begin{tabular}{|c|c|c|}
\hline Abbreviations & Description & Unit \\
\hline EPIAV & Electric power industrial added value & $10^{8}$ yuan \\
\hline EPIWSQ & $\begin{array}{l}\text { Electric power industrial water use } \\
\text { quantity }\end{array}$ & $10^{8} \mathrm{~m}^{3}$ \\
\hline EPIWUE & $\begin{array}{l}\text { Electric power industrial water } \\
\text { utilization efficient }\end{array}$ & \\
\hline TFEPIWSQ & $\begin{array}{l}\text { Table function of electric power } \\
\text { industrial water use quota }\end{array}$ & $\begin{array}{r}\mathrm{m}^{3} / 10^{4} \\
\text { yuan }\end{array}$ \\
\hline EUCEPWS & $\begin{array}{l}\text { Effective utilization coefficient of } \\
\text { electric power water use }\end{array}$ & \\
\hline $\mathrm{AC}$ & Adjustment coefficient & \\
\hline TIAV & The tertiary industrial added value & $10^{8}$ yuan \\
\hline PTIAV & The proportion of TIAV & $\%$ \\
\hline TFPTIAV & Table function of PTIAV & $\%$ \\
\hline TFTIAV & Table function of per $10^{4}$ yuan TIAV & $\begin{array}{r}\mathrm{m}^{3} / 10^{4} \\
\text { yuan }\end{array}$ \\
\hline RDWSQ & Rural domestic water use quantity & $10^{8}$ yuan \\
\hline TFRDWUQ & $\begin{array}{l}\text { Table function of rural domestic water } \\
\text { use quota }\end{array}$ & L/day \\
\hline $\mathrm{RP}$ & Rural population & $10^{4}$ person \\
\hline TP & Total population & $10^{4}$ person \\
\hline PG & Population growth & $10^{4}$ person \\
\hline PGR & Population growth rate & $\%$ \\
\hline TFPGR & $\begin{array}{l}\text { Table function of population growth } \\
\text { rate }\end{array}$ & $\%$ \\
\hline UDWSQ & Urban domestic water use quantity & $10^{8}$ yuan \\
\hline TFUDWUQ & $\begin{array}{l}\text { Table function of urban domestic water } \\
\text { use quota }\end{array}$ & L/day \\
\hline NRP & Non-rural population & $10^{4}$ person \\
\hline UR & Urbanization rate & $\%$ \\
\hline TFUF & Table function of urbanization rate & $\%$ \\
\hline ACUR & $\begin{array}{l}\text { Adjustment coefficient of urbanization } \\
\text { rate }\end{array}$ & \\
\hline GDP & Gross domestic production & $10^{8}$ yuan \\
\hline GGDP & Growth of gross domestic production & $10^{8}$ yuan \\
\hline GRGDP & $\begin{array}{l}\text { Growth rate of gross domestic } \\
\text { production }\end{array}$ & $\%$ \\
\hline TFGRGDP & Table function of growth rate of GDP & $\%$ \\
\hline GDPWUQ & Per $10^{4}$ yuan GDP water use quantity & $\begin{array}{r}\mathrm{m}^{3} / 10^{4} \\
\text { yuan }\end{array}$ \\
\hline WRSQ & Water resource supply quantity & $10^{8} \mathrm{~m}^{3}$ \\
\hline TFWRSQ & $\begin{array}{l}\text { Table function of water resource supply } \\
\text { quantity }\end{array}$ & $10^{8} \mathrm{~m}^{3}$ \\
\hline BRWRSD & $\begin{array}{l}\text { Balance ratio between water resource } \\
\text { supply and demand }\end{array}$ & \\
\hline BFWR & The balance factor of water resources & \\
\hline
\end{tabular}

\section{References}

Comez CM, Tiradod D, Rey MJ (2004) Water exchange versus water works: insights from a computable general equilibrium model for the Balearic Islands. Water Resour Res 40(10):1-11 
Davies EGR, Simonovic SP (2011) Global water resources modeling with an integrated model of the social-economic-environmental system. Adv Water Resour 34:684-700

Dawadi S, Ahmad S (2012) Changing climatic conditions in the Colorado River basin: implications for water resources management. J Hydrol 430-431:127-141

Dawadi S, Ahmad S (2013) Evaluating the impact of demand-side management on water resources under changing climatic conditions and increasing population. $\mathrm{J}$ Environ Manage 114:261-275

Fang GH, Zhong JL, Wu XW (2010) The utilization of water resources and the prevention and control of water pollution based on input output optimal control model. J Hydraul Eng 41(9):1128-1134

Forrester Jay W (1971) World dynamics [M]. The MIT Press, Cambridge

Hassanzadeh E, Elshorbagy A, Wheater H, Gober P (2014) Managing water in complex systems: an integrated water resources model for Saskatchewan, Canada. Environ Model Softw 58:12-26

Hu SY, Wang ZZ, Wang YT (2010) The unified allocation model of the allowed water intake and permitted discharge amount based on total amount control. China series E: Scientia Sinica 40(10):1130-1140

Jennifer M (2005) Water Institutional Reforms in Australia. Water Policy 7(1):35-52

Kang SZ, Jia XL, Du TS (2009) Scale water resources transformation rules and water saving regulation pattern in the arid areas of Northwest China, use Shiyang River basin in Gansu as an example. Chinese Water Conservancy and Hydropower Press, Beijing

Kojiri T, Hori T, Nakatsuka J, Chong TS (2008) World continental modeling for water resources using system dynamics. Phys Chem Earth 33:304-311

Liao MQ (2009) Analysis of the input output and its extension. Capital University of Economics and Business press, Beijing

Qi C, Chang NB (2011) System dynamics modeling for municipal water demand estimation in an urban region under uncertain economic impacts. J Environ Manag 92:1628-1641

Qin HP, Su Q, Khu ST (2011) An integrated model for water management in a rapidly urbanizing catchment. Environ Model Softw 26:1502-1514
Rehan R, Knight MA, Unger AJA, Haas CT (2013) Development of a system dynamics model for financially sustainable management of municipal water main networks. Water Res 47:7184-7205

Shen DJ, Chen W, Luo JP (2006) Econometric analysis and application on urban household water use. J Hydraul Eng 37(5):593-597

Stave KA (2003) A system dynamics model to facilitate public understanding of water management options in Las Vegas, Nevada. J Environ Manag 67:303-313

Sušnik J, Vamvakeridou-Lyroudia LS, Savić DA, Kapelan Z (2012) Integrated system dynamics modelling for water scarcity assessment: case study of the Kairouan region. Sci Total Environ 440:90-306

CPC Central Committee, State Council (2011) CPC Central Committee and State Council on accelerating the development of water conservancy reform decision. China Water Diary 2:1

The Sustainable Development Strategy Group of China of Sciences Research Academy (2007) Sustainable development report of China. Water: governance and innovation. Science Press, Beijing

Wang QF (1995) Senior system dynamics. Tsing Hua University Press, Beijing

Wang Z (2004) Simulate and analysis environmental economic security policy of China. Science Press, Beijing

Wang S, Xu L, Yang FL, Wang H (2014) Assessment of water ecological carrying capacity under the two policies in Tieling City on the basis of the integrated system dynamics model. Sci Total Environ 472:1070-1081

Winz I, Brierley G, Trowsdale S (2009) The use of system dynamics simulation in water resources management. Water Resour Manag 23:1301-1323

Zarghami M, Akbariyeh S (2012) System dynamics modeling for complex urban water systems: application to the city of Tabriz, Iran. Resour Conserv Recycl 60:99-106

Zhang XH, Zhang HW, Chen B et al (2008) Water resources planning based on complex system dynamics: a case study of Tianjin city. Commun Nonlinear Sci Numer Simul 13:2328-2336

Zhang WX, Lu Y, Zhao WB (2014) Development tendency analysis and evaluation of the water ecological carrying capacity in the Siping area of Jilin Province in China based on system dynamics and analytic hierarchy process. Ecol Model 275:9-21

Zhao Y, Wang JF, Cai HJ (2008) The review of CGE models on water resources problems. Adv Water Sci 19(5):756-762 